\title{
STRUCTURE OF PARFUMIDINE
}

I. A. Israilov, M. S. Yunusov, and S. Yu. Yunusov

Khimiya Prirodnykh Soedinenii, Vol. 6, No. 4, pp. 493-494, 1970

UDC $547-943$

Continuing the separation of the combined alkaloids of Fumaria parviflora Lam. [1], we have isolated a base with the composition $\mathrm{C}_{21} \mathrm{H}_{21} \mathrm{O}_{5} \mathrm{~N}$, mp $170-171^{\circ} \mathrm{C}$ (methanol), $[\alpha]_{\mathrm{D}}^{22}+33.3^{\circ}$ (c 0.5 , chloroform), mol wt 367 (mass spectrometry). The base proved to be new and we have called it "parfumidine." The IR spectrum of the alkaloid has absorption bands at $\left(\mathrm{cm}^{-1}\right) 915$ and 1020 (methylenedioxy group), 1520 and 1620 (aromatic ring), and 1720 (carbonyl group). UV spectrum, $\lambda_{\max }, \mathrm{m} \mu: 235,263,290$, and $360(\log \varepsilon 4.46,4.14$, inflection, and 340$)$. In the NMR spectrum (taken on a JNM-4H-100/100 MHz spectrometer in deuterochloroform) there are a three-proton singlet from $\mathrm{N}-\mathrm{CH}_{3}$ at $2.28 \mathrm{ppm}(\delta$ scale, HMDS), two three-proton singlets at 3.52 and 3.77 ppm from two methoxy groups, a two-proton singlet at $6.07 \mathrm{ppm}$ from a methylenedioxy group, two one-proton singlets at 6.13 and $6.52 \mathrm{ppm}$ from para aromatic protons, two one-proton doublets at 6.83 and $7.03 \mathrm{ppm}(\mathrm{J}=8 \mathrm{~Hz})$ from ortho aromatic protons, and a multiplet at $2.6-3.6 \mathrm{ppm}$ corresponding to six methylene protons. The UV, IR, and NMR spectra of parfumidine are similar to the spectra of parfumine and fumariline [2,3]. On the basis of these facts, the formula developed for parfumidine is as follows.

$$
\mathrm{C}_{16} \mathrm{H}_{10}\left(\mathrm{OCH}_{3}\right)_{2}\left(\mathrm{CH}_{2} \mathrm{O}_{2}\right)(\mathrm{CO})\left(\mathrm{N}-\mathrm{CH}_{3}\right) \text {. }
$$

We can see from a comparison of the formulas developed for parfumine (II) and parfumidine that the latter has a second methoxyl group in place of the hydroxyl in parfumine. The UV, IR, NMR, and mass spectra of parfumidine and of O-methylparfumine [2] obtained by the methylation of parfumine with diazomethane are identical. A mixture of the two substances gave no depression of the melting point. Thus, parfumidine has the structure I.

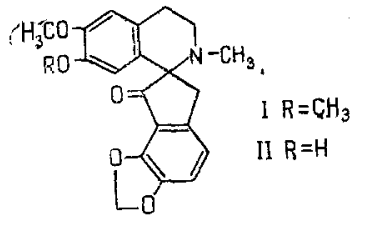

\section{REFERENCES}

1. I. A. Israilov, M. S. Yunusov, and S. Yu. Yunusov, KhPS [Chemistry of Natural Compounds], 4, 194, 1968.

2. I. A. Israilov, M. S. Yunusov, and S. Yu. Yunusov, DAN SSSR, 189, 1262, 1969.

3. J. K. Saunders, R. A. Bell, C. Y. Chen, D. B. McLean, and R. H. F. Manske, Can. J. Chem., 46, 2873,1968 .

20 March 1970

Institute of the Chemistry of Plant Substances, AS UzSSR 